TEME, г. ХLII, бр. 3, јул - септембар 2018, стр. 1043-1060

Оригинални научни рад

DOI: 10.22190/TEME1803043D

Примљено: 25. 4. 2017.

UDK 343.341(497.11)

Одобрено за штампу: 12. 6. 2018.

\title{
КАРАКТЕРИСТИКЕ ОСУЂЕНИЧКИХ БАНДИ У РЕПУБЛИЦИ СРБИЈИ
}

\author{
Дарко Димовски* , Миомира Костић \\ Универзитет у Нишу, Правни факултет, Ниш, Србија \\ *darko@prafak.ni.ac.rs
}

\begin{abstract}
Апстракт
Полазећи од појма осуђеничких банди, који су дали познати пенолози Карлсон, Гарет, Флајшер, Ризон и други, аутор је нагласио да до сада предмет емпиријског истраживања нису биле банде затвореника у казненим установама Републике Србије. Стога је било неопходно провести истраживање ради утврђивања карактеристика осуђеничких банди у Републици Србији, при чему би дошло до упоређивања добијених резултата са карактеристикама банди осуђеника у америчком казненом систему. Аутори су у раду анализирали структуру осуђеничких банди у Казнено-поправном заводу у Нишу и у Казнено-поправном заводу за малолетнике у Ваљеву, уз навођење начина напредовања у структури банде. Основ постојања банди у затворима је бављење криминалним активностима. Пре него што су се бавили које су то криминалне активности осуђеничких банди у нишком Казнено-поправном заводу и Казнено-поправном заводу за малолетнике у Ваљеву, аутори су навели која кривична дела врше банде затвореника у америчким затворима, истичући да се те криминалне активности међусобно не разликују. Један од начина заштите вршења криминалних активности у затворима је употреба насиља. Док се до података о насиљу међу осуђеничким бандама у америчким затворима може лако доћи, управа Казнено-поправног завода у Нишу, као ни управа затвора за малотнике, не води такву евиденцију, те је немогуће сазнати да ли је до примене одређеног насиља у казненој установи дошло као резултат поремећених односа у једној осуђеничкој банди, односно као резултат сукоба са другом осуђеничком бандом, или услед неких других околности. Међутим, и поред тога, до примене насиља од стране осуђеничке банде долази због кршења кодекса понашања. Комуникација осуђеничких банди мора се одвијати на дискретан начин уз отежавање сазнања пренесених порука од стране управе затвора. Стога се користе разне шифроване поруке у америчким затворима. За разлику од њих, банде осуђеника у Казнено-поправном заводу у Нишу и Казнено-поправном заводу за малолетнике у Ваљеву не користе шифроване поруке, говор тела за међусобну комуникацију, као ни посебан код. Разлог томе треба тражити у чињеници да осуђеничке банде у затвору у Нишу не представљају такву претњу која онемогућава функционисање саме казнене установе вршењем различитих кривичних дела, те стога нема потребе за посебном заштитом комуникације чланова колектива. Последњи део рада посвећен је кодексу понашања, уз навођење правила која су морају поштовати.
\end{abstract}

Кључне речи: осуђеничке банде, Република Србија, казнени систем. 


\title{
CHARACTERISTICS OF PRISON GANGS IN THE REPUBLIC OF SERBIA
}

\begin{abstract}
Starting from the concept prison gangs, who have given famous penologists Carlson, Garrett, Fleischer, Reason and others, the author pointed out that until now the subject of empirical research were not gangs of inmates in penitentiary institutions of the Republic of Serbia. Therefore, it was necessary to conduct a study to determine the characteristics of prison gangs in Serbia, where it came to comparing the results obtained with the characteristics of a gang of convicts in the US penitentiary system. The author has analyzed the structure of prison gangs in a correctional institution in Niš and in a correctional institution for juveniles in Valjevo, stating the mode of progression in the structure of gangs. The basis of the existence of gangs in prisons is engaging in criminal activities. Before he dealt what are the criminal activities of prison gangs in a correctional institution in Niš and in a correctional institution for juveniles in Valjevo, the author stated that the crimes carried out gangs of prisoners in US jails, noting that these criminal activities do not differ. One of the ways of carrying out criminal activities in prisons is the use of violence. While data on violence among convicts gangs in American prisons can be easily reached, the management of the correctional facility in Niš, as well as in a correctional institution for juveniles in Valjevo, does not keep such records, and it is impossible to know whether a particular violence in penitentiry institution has been set up as a result of relations in a prisoner gangs, and as a result of the conflict with the other prisoners' band, or due to other circumstances. However, in addition to the use of violence by prisoners' gang is due to code violations. Communication of prison gangs must be done in a discreet way with hindering information messages transmitted by the prison administration. Therefore, using a variety of encrypted messages in American prisons. Unlike them, the gang of convicts in a correctional facility in Niš and in a correctional institution for juveniles in Valjevo do not use an encrypted message, body language to communicate with each other, as well as a special code. The reason for this is the fact that prisoners' gang in prison in Niš and in prison for juveniles in Valjevo do not pose such a threat that prevents the functioning of the penitentiary institution committing various criminal acts, and therefore there is no need for special protection of communications of members of the prison gangs. The last part is dedicated to the code of conduct, stating the rules that must be respected.
\end{abstract}

Key words: prisoner gangs, Republic of Serbia, penitentiary system.

УВОД

Под термином осуђеничке банде подразумевамо различите врсте банди које постоје у казненим установама. Осуђеничке банде су врста криминалне организације које су настале у америчким затворима. Иако припадници различитих стручних служби имају тенденцију да не употребљавају термин банда, сагласни су међу собом да постојање ових неформалних група представља велики ризик за сигурност свих у затворима (Костић, Димовски, 2013, стр. 221). Затворске банде могу се одредити и као субјекти који извршавају кри- 
вична дела, при чему испољавају контролу над уличним бандама. На тај начин њихов утицај превазилази границе самог затвора. ${ }^{1}$

Једно друго одређење затворских банди односи се на одређену групу осуђеника, код које постоји одређени степен хијерархије. Неки су сматрали да се традиционалне осуђеничке банде састоје само од пунолетних осуђеника, уз постојање хијерархије са различитим позицијама унутар банде. Другим речима, под осуђеничком бандом подразумева се веома ефикасна криминална организација, која успева да прокријумчари психоактивне супстанце у саму казнену установу, уз постојање других криминалних активности како би се одржао такав положај (Carlson, Garrett, 2008, p. 32).

Пенолози Флајшер и Ризон наглашавају да се појам осуђеничке банде везује за групу осуђеника која има велики капацитет за ремећење мира у затворима или за групу осуђеника који представљају претњу за општу безбедност (Hensley, 2002, p. 4).

Пенолог Лајман, на пример, одређује осуђеничке банде као организацију која делује у оквиру затворског система, која се састоји од одабране групе затвореника, уз постојање ланца команде и кодекса понашања. Осуђеничке банде одликују се тајношћу, при чему је циљ постојања осуђеничке банде бављање криминалним активностима, којим се уједно врши контрола над непосредним окружењем у затворима, применом насиља и застрашивања према осуђеницима који нису чланови банде. За осуђеничке банде може се рећи да за пенологе представљају веома проблематично и непредвидиво истраживање, као што за управу у казненим установама представљају ноћну мору (Fleisher, Decker, 2001, p. 2).

До сада осуђеничке банде у Републици Србији нису биле предмет емпиријског истраживања. Стога је неопходно извршити емпиријско истраживање о бандама осуђеника у казненом систему Републике Србије. Ради утврђивања карактеристика осуђеничких банди у Републици Србији, спроведено је пенолошко истраживање банди затвореника у Казнено-поправном заводу у Нишу и Казнено-поправном заводу за малолетнике у Ваљеву током 2015. године, при чему је био примењен интервју на основу унапред састављених питања. Надаље у раду аутори ће представити добијене резултате уз упоређивање добијених карактеристика са одликама осуђеничких банди у Сједињеним Америчким Државама.

${ }^{1}$ Prison Gang Law \& Legal Definition, http://definitions.uslegal.com/p/prison-gang/, 23. јун 2013. 


\section{СТРУКТУРА ОСУЂЕНИЧКИХ БАНДИ}

Организација осуђеничких банди била је предмет истраживања у бројним случајевима. Наиме, доцент на катедри за криминологију Роберт Фонг на Универзитету Северна Каролина проучавао је структуру двеју осуђеничких банди: Texas Syndicate и Mexikanemi. Као општу карактеристику осуђеничких банди наводио је висок степен структурисаности. Тако је, на пример, на челу банде Texas Syndicate председник и потпредседник, који су изабрани од стране других припадника банде. Из овога се може извући закључак да у организацији Texas Syndicate провејава дух демократије, јер сваки члан има право гласа, а одлуке се доносе јединствено. Правило о неопходности постизања јединствених одлука уведено је како би се спречио могући сукоб. Фонг је сматрао да се јединица организација ове осуђеничке банде састоји од команданта, који је надређен капетану, поручнику, воднику и војнику. Као услов за долазак на све друге позиције, осим позиције председника, јесте доказаност у обављању кривичних дела за саму банду. Један од начина заштите банде од избијања унутарњег сукоба је и правило да сви чланови ове осуђеничке банде, осим председника и потпредсеника, бивају одмах деградирани у положај војника уколико их управа формалног система премести у неку другу групу (Orlando-Morningstar, 1997, p. 5).

Осуђеничка банда Mexikanemi има, како тврди Фонг, сличну организацију. На челу банде је председник, а испод њега постоје потпредседник, регионални генерали, поручници, водници и војници. Како би се досегла одређена позиција у структури саме банде, потребно је располагати посебним вештинама, које се огледају у могућности одржавања хармонијских односа у самој банди, као и у поседовању лидерских способности. Иако је одржавање складних односа у самој банди веома важан елемент с циљем даљег јачање снаге банде, у осуђеничкој банди Mexikanemi не постоји унапред смишљен начин избегавања сукоба међу члановима банде. Иако је један од принципа функционисања банде постизање јединствених одлука, поручници често издају наредбе, без претходне сагласности осталих чланова банде (Orlando-Morningstar, 1997, p. 5).

Из овог истраживања криминолога Роберта Фонга могу се извући неки уопштени закључци о организацији осуђеничких банди. Наиме, оне су високо организоване осуђеничке групе, са одређеним кодексом понашања и правилима понашања, која се спроводе од стране вође банде (Miller, Hess, Orthmann, 2011, p. 386). На челу сваке осуђеничке банде је вођа, заједно са својим блиским сарадницима. Вођа затворске банде одликује се честом употребом насиља, како према члановима његове банде тако и према осуђеницима који нису припадници његове банде, при чему је способан да застраши друге затворенике. Пенолошкиња Сандра Фортун је, приликом истражива- 
ња осуђеничких банди, дошла до шест особина вођа банди у затворима. Тако се вођа затворске банде карактерише захтевом за лојалношћу од других припадника банде, спровођењем сопствених жеља и одржавању тренутне позиције уливањем страха осталим члановима банде, способношћу и жељом да спроведе своје наредбе, потврђивањем своје позиције у односу на остале чланове банде, успоном до позиције вође банде коришћењем личних веза са претходним вођом, као и потврђивању самог себе као лидера осуђеника кроз призму поштовања, које је стекао због свог понашања и показивања способности вође (Holmes, Tewksbury, Higgins, 2012, p. 120).

Владајућа структура, са најтврђим члановима банде, чини 15$20 \%$ укупног чланства банде. Чланство у осуђеничкој банди подразумева апсолутну лојалност. Начин напредовања на хијерархијској лествици подразумева употребу (смртоносне) силе. Не постоји могућност да неко изађе из банде, јер се сматра да он тиме угрожава виталне интересе саме банде осуђеника, тако да се то лице елиминише (Fleisher, et al., 2001, p. 3).

За разлику од структуриране групе осуђеника у Сједињеним Америчким Државама које се називају осуђеничке банде, у казненом систему Републике Србије постоје групе осуђеника за чије означавање се користи појам колектив. Наиме, употребљава се термин колектив за означавање структуриране групе осуђеника са постојањем кодекса понашања и ланца команде. Казнено-поправни завод у Нишу је казнена установа са максималним степеном обезбеђења у којој казну затвора издржавају лица осуђена на капиталну казну. Основ формирања колектива у нишком Казнено-поправном заводу је порекло, односно пребивалиште затвореника. Сваки од колектива, који постоји унутар Казнено-поправног завода у Нишу, састоји се од вође, заменика вође, као и од војникаิ. Услов за чланство унутар једног колектива је „исправност”, при чему се под њом подразумева нецинкарање. Наиме, за чланство је неопходно да постоји препорука, која се односи на поступак проверавања од чланова колектива да ли је одређени новопридошли затвореник одао своје сараднике при извршењу кривичног дела или не. Уједно, унутар казнене установе постоје тзв. цинкароши и неутралци. Они су задужени за прање ствари осталим затвореницима, за чишћење колективних просторија итд. Неутралац се постаје на основу сопствене одлуке. Наиме, дати затвореник не жели да буде члан било којег колектива. На тај начин не ужива заштиту од стране припадника одређеног колектива, али и не дели њихова правила понашања, као и хијерархијски однос. Као основ напредовања у хијерархији одређеног колектива је учествовање у тучама, штанглирањима, бодењима итд. Вођа постаје затвореник са највећим ауторитетом. До привремене замене вође долази у два случаја. Тако, на пример, до привремене замене вође колектива 
долази у случају ситуације када је у физичком обрачуну са припадницима другог колектива претучен тако да не може више да руководи својим колективом. Још један разлог да вођа колектива буде привремено замењен је ситуација у којој је он, због кршења дисциплинских правила понашања, пребачен у одељење појачаног разлога надзора. Поред привремене замене вође колектива, постоје околности које за резултат имају да друго лице преузме руковођење колективом за стално. Наиме, излазак на слободу по издржаној казни затвора резултира његовом заменом другим припадником колектива за стално. До замене вође за стално може доћи у случају физичког обрачуна вође са другим припадником колектива, при чему као победник физичког обрачуна изађе претендент на место вође колектива.

Казнено-поправни завод за малолетнике у Ваљеву је таква казнена установа у коју се упућују малолетници на издржавање казне малолетничког затвора. Наиме, временом се бројност колектива у Казнено-поправном заводу за малолетнике мењала. Од почетка 21. века постојало је пет колектива: београдски, сељачки, земунски, цигански и клошарски. Основ за чланство у било којем колективу је само порекло осуђеног малолетника. Наиме, пребивалиште у одређеном граду неминовно је значило чланство у колективу у којем су припадници малолетници из датог града. Београђани су били чланови тзв. београдског колектива, док Земунци, због наглашеног локалпатриотизма, нису желели да буду чланови истог колектива као и остали малолетници пореклом из Београда, већ су оформили сопствени колектив - земунски. Уједно, битно је напоменути да се чланство у београдском колективу, који је „најпрестижнији”, могло остварити уколико је малолетник доброг финансијског стања, на основу чега би чланови београдског могли да узимају преко потребан новац. Чланови тзв. сељачког колектива били су малолетници пореклом из других градова широм Републике Србије. Од правила о чланству у колективу на основу пребивалишта постојало је неколико изузетака. Основ за чланство у одређени колектив био је и припадност одређеном етничком пореклу. Стога су припадници ромске националности имали свој колектив под називом циигански колектив. Уједно, малолетници који због својих ставова нису желели да буду чланови неког колектива били су задужени за прање ствари, одношење, као и доношење ствари припадника осталих колектива.

У другој половини те деценије дошло је до смањивања броја колектива, при чему су остала само два колектива - београдски и сељачки. Међутим, временом се број колектива смањио, што је допринело и другачијој организационој структури колектива. Сваки од два преостала колектива - београдски и сељачки - имао је структуру коју су чинили колективци, бандити и клошари. У оквиру колективаца постоји даља подела на вођу, подвође и колективце. Вођа и две 
или три подвође чине руководећи део колектива, као и колективаца. Уједно, треба нагласити да колективци раде оно што им кажу вође, те својим ауторитетом не могу да утичу на бандите, већ само на клошаре. Њихов примарни задатак је продаја психоактивних супстанци, стероида и мобилних телефона под директном контролом вође. Улога бандита у београдском и сељачком колективу је обрачунавање са члановима супротног колектива. Један човек представља вођу бандита. Улога клошара у оквиру београдског и сељачког колектива била је служење захтевима осталих чланова колектива у виду прања веша, чишћења заједничких просторија и спаваона, поспремање столова за оброк итд.

Поред малолетника који су били чланови колектива, постоје и малолетници који изразе жељу да не буде чланови било којег од преостала два колектива. Њихов положај у оквиру неформалне заједнице доста је неповољнији у односу на остале малолетнике чланове колектива. Наиме, они су могли да буду само у ходнику зграде у близини чувара и уједно су се сматрали цинкарошима.

\section{КРИМИНАЛНЕ АКТИВНОСТИ ОСУЂЕНИЧКИХ БАНДИ}

Основна сврха постојања осуђеничких банди је бављење одређеним криминалним активностима. Наиме, осуђеничке банде у затворима широм Сједињених Америчких Држава баве се продајом психоактивних супстанци унутар установа. Психоактивне супстанце се набављају у сарадњи са уличним бандама, које се у одређеним случајевима састоје од бивших осуђеника који су и сами били чланови банди у казненим установама. Тржиште психоактивних супстанци на југозападу Сједињених Америчких Држава је под директном контролом банди осуђеника, при чему се психоактивне супстанце набављају у сарадњи са уличном бандом под називом Mexican DTOs (Miller, et al., 2011, p. 386). Уједно, једна од карактеристика осуђеничких банди је и бављење проституцијом, изнуђивањем, вршењем плаћених убистава, као и заштитом појединих важних појединаца из криминалног миљеа (Orthmann, Hess, 2012, p. 598).

Неки пенолози бавили су се и проучавањем криминалних активности појединих осуђеничких банди у америчком казненом систему. Тако се осуђеничка банда Mexican Mafia (EME) претежно бави продајом психоактивних супстанци не само унутар казнене установе већ и ван затворских зидина. Уједно, чланови ове банде укључени су и у друге криминалне активности, које обухвата организовање проституције и нелегалног коцкања (Mays, Winfree, 2008, p. 208).

Осуђеничка банда која се врло често меша са Мексичком мафијом је банда затвореника по имену Mexikanemi. Неки их називају и именом Texas Mexican Mafia. Добро су повезани са својим сарадни- 
цима ван затвора, што им омогућује тржиште дрогом како ван зидина затвора тако и у самом затвору (Lyman, 2011, p. 497). Чланови банде се често повезују са почињеним убиствима (Orlando-Morningstar, 1997, p. 4).

Осуђеничке банде у српском казненом систему баве се, као и банде осуђеника у америчким затворима, различитим криминалним активностима. Наиме, осуђеничке банде, тзв. колективи, у Казненопоправном заводу у Нишу баве се продајом наркотика. До уношења психоактивних супстанци долази на више начина. Наиме, један од начина уношења психоактивних супстанци је преко посета затвореницима. Уједно, психоактивне супстанце крију се унутар пакета који се шаљу одређеним припадницима колектива. Начин уношења наркотика, који је најопаснији за функционисање формалног система и његове улоге у ресоцијализацији затвореника, јесте њено кријумчарење преко појединих припадника службе обезбеђења или службе за третман. С циљем уношења психоактивних супстанци у казнену установу, припадник службе обезбеђења или службе за третман буде контактиран од стране особе ван затвора, која даје припаднику формалног система новац ради уношења у казнену установу одређене количине психоактивне супстанце. Лице које је задужено за успостављање контакта са припадником формалног система често је бивши припадник колектива који по изласку из затвора наставља да негује везу са члановима свог бившег колектива. Дилери дроге, иначе чланови одређених колектива, стоје поред радијатора у ходницима затворских крила, при чему се продаја психоактивне супстанце врши веома брзо. Места чувања психоактивних супстанци налазе се унутар одређених затвореничких соба. Један од начина остваривања профита у Казненој установи у Нишу је и зеленашење. Наиме, новац се враћа после одређеног времена са зеленашком каматом на тај начин да особа ван затворских зидина, која је у блиској емотивној или родбинској вези са зајмопримцем, уплаћује одређену количину новца зајмодавцу на кантину, при чему се тај новац користи за куповину неопходних ствари за свакодневни живот, или се одређена количина новца уплаћује на рачун који је претходно дат од стране зајмодавца. Поред позајмљивања пара, неки чланови колектива позајмљују цигарете или хало-картице. Наиме, цигарете и хало-картице на овај начин имају функцију новца, јер се њима могу куповати неопходне ствари код појединих чланова колектива који се баве њиховом препродајом. Њиме се могу купити и наркотици, под условом да се дају у вредности наркотика који се купује. Како се цигарете могу купити у затворској кантини, њихова вредност међу осуђеницима је истоветна цени у самој кантини. Последња криминална активност чланова колектива је и отимање пакета затвореницима који су етикетирани као цинкароши или као неутралци. 
Колективи у оквиру Казнено-поправног завода за малолетнике у Ваљеву бавили су се различитим криминалним активностима. Наиме, једна од најпрофитабилнијих криминалних активности је продаја психоактивних супстанци у оквиру саме установе по цени која је била неколико пута већа него на слободи. Дрога се уносила путем договора са појединим командирима, који су зарад остваривања одређене новчане користи пристајали да ризикују губитак службе и одлазак у затвор. Занимљив је податак да се генерацијски преносило знање на новопридошле чланове колектива о томе да поједини припадници формалног система уносе психоактивне супстанце. Криминална веза између појединих припадника формалног система и појединих чланова колектива огледа се и код продаје мобилних телефона. Наиме, већ продати телефони буду после одређеног времена заплењени од стране појединих припадника формалног система након дојаве од стране појединих чланова колектива о томе у чијем поседу се налазе. Убрзо ти исти телефони се поново продају унутар саме казнене установе, чиме се обезбеђује вишеструка новчана корист на основу продаје истих мобилних телефона. Уједно, начин остваривања профита колективаца је и продаја цигарета и стероида за тренинг, као и зеленашење. Психоактивне супстанце, као и мобилни телефони, набављају се преко тзв. спољњег човека, иначе бившег члана колектива, који их предаје одређеним командирима ради уношења у казнену установу. Уједно, постојала је могућност сарадње међу колективима, уколико је дошло до ситуације да вођа једног од колектива има добре контакте са одређеним припадником службе обезбеђења који је спреман да унесе унутар казнене установе наркотике. Наиме, тада се вође различитих колектива договоре да се све уношење наркотика врши преко датог командира, чак и за потребе припадника другог колектива.

\section{ОСУЂЕНИЧКЕ БАНДЕ И НАСИЉЕ}

Бројне криминолошке студије показале су да лица која су највише склона насиљу, како ван затвора тако и у самом затвору, имају између 16 година и 24 године. Просечна старост лица која долазе у пријемна одељења казнених установа је 27 година. Такође, дошло се до резултата да су младе особе у већој могућности да буду жртве разних облика насиља у односу на лица старије животне доби (Clear, Cole, Reisig, 2009, p. 278). Непостојање породичних веза младих осуђеника је још један разлог њихове склоности ка испољавању насиља. Као још један разлог да су млади осуђеници насилнији у односу на старије осуђенике, наводи се њихова немогућност да међусобне односе са другим осуђеницима не тумаче као изазове и провокације, 
што у крајњем случају доводи до испољавања насилног понашања (Clear, et al., 2009, p. 278).

Осуђеничке банде су главни „произвођачи” насиља у затворима. Расна и етничка припадност су главни поводи за нападе на припаднике других банди. У казненим установама долази до „преливања" насиља са улице у саме затворе. Другачије речено, рат на улици између припадника различитих банди преноси се међу затворске зидине (Clear, et al., 2009, p. 278).

Истраживање о обиму насиља у казненим установама показало је да су од 82.000 осуђеника највише насилни они који припадају осуђеничким бандама. Чланови различитих банди одговорни су за $26 \%$ насилних инцидената, као и за $31,5 \%$ насилних напада на друге осуђенике. Припадници формалног система примењују припадност осуђеничким бандама као најбитнији фактор у прогнози понашања неког осуђеника током издржавања казне затвора. Исто тако, већа укљученост у криминалне активности, као и већа позиција у хијерархији осуђеничке банде, представља битан показатељ насилног понашања (Holmes, et al., 2012, p. 121).

Детаљна истраживања о обиму насиља у казненим установама Републике Србије почињеним од стране припадника различитих колектива не постоје. Иако се воде евиденције о обиму насиља у српским казненим установама, ни у једној статистичкој евиденцији није могуће наћи податак да ли је конкретан насилни догађај произашао као резултат нарушавања односа унутар колектива или сукоба међу њима. Наиме, до сукоба међу затвореницима може доћи из разлога чији се основ налази у кривичном догађају у којем је учествовало више лица која се сада налазе на издржавању казне затвора. Стога разлоге вербалних и физичких сукоба не треба тражити само у односима међу колективима и њиховим члановима већ и у односима међу затвореницима/штићеницима из њихових живота пре доношења одлуке кривичног суда.

Иако је немогуће доћи до података о тачном обиму насиља у колективима у Казнено-поправном заводу у Нишу, треба напоменути да је оно и те како присутно, јер се оно јавља уколико дође до неког вербалног сукоба између припадника различитих колектива унутар казнене установе у Нишу - начин решавања вербалног сукоба се огледа или у тучи један на један или у физичком обрачуну целокупних колектива̂. До примене насиља према члану колектива долази у случају цинкарења. Наиме, стварност у Казнено-поправном заводу у Нишу је таква да за цинкарење следује штанглирање у соби која је најудаљенија од затворских чувара. Након тога, цинкарош се ставља на ћебе и вуче до решетке које одвајају затворске ћелије од просторије у којој се налазе чувари. Члан истог колектива може бити жртва насиља и под околностима да не може да измири дуг за плаћање 
психоактивне супстанце коју је већ користио. Наиме, тада долази до шамарања и другог малтретирања, што на крају може резултирати избацивањем из колектива.

И у Казнено-поправном заводу за малолетнике у Ваљеву се не води евиденција о обиму насиља међу осуђеницима на тај начин да се може сазнати да ли је физички сукоб резултат поремећених односа између чланова колектива. Ипак, животне околности су такве да је психичко или физичко насиље свакодневна појава у установи. Тако ради прихватања од стране сељачког колектива, новопридошли члан је још за време боравка у пријемном одељењу нанео тешке телесне повреде двојици малолетника. Након доласка у круг имао је, како је сам нагласио, још две-три ситуације са припадницима београдског колектива, на основу чега је постао вођа сељачког колектива. До примене насиља према члану сопственог колектива долазило је услед кршења правила понашања, такозваног кодекса.

\section{КОМУНИКАЦИЈА ОСУЂЕНИЧКИХ БАНДИ}

Чланови осуђеничких банди користе различите начине како би комуницирали. Неки истраживачи сматрају да чланови осуђеничких банди комуницирају употребом тетоважа и графита. Најчешће се користе шифроване поруке (Riviello, 2010, 196). Поред комуникације међу члановима осуђеничких банди помоћу шифара, чланови банде осуђеника користе и тзв. говор тела (енгл. body language), који обухвата комуницирање телом, рукама, као и посебним плесним покретима. Комуницирање телом односи се на посебан положај руку и ногу, којим се шаљу одређене поруке члановима савезничних или противничких банди осуђеника. Неке банде затвореника имају дубоко укорењене церемонијалне плесове, који се састоји од понављања одређених комбинација покрета петом и прстима. Сврха тих плесова је увреда чланова супарничке банде, мада се плес изводи и након убиства члана неке друге банде осуђеника (Riviello, 2010, 197). Неке друге банде осуђеника комуницирају међусобно помоћу посебног кода, под којим се подразумева употреба одређених речи, које за чланове затворске банде имају посебно значење.

За разлику од осуђеничких банди у казненим установама Сједињених Америчких Држава, осуђеничке банде у казненим установама, познате под називом колективи, не користи шифроване поруке, говор тела за међусобну комуникацију, као ни посебан код. Наиме, комуникација међу члановима колектива одвија се нормалним путевима. Разлоге разликовања у начину комуникације међу члановима осуђеничких банди у Сједињеним Америчким Државама и Републици Србији треба тражити у капацитету вршења кривичних дела унутар и ван затвора од стране осуђеничких банди у америчким 
затворима. Стога је потребно заштитити вршење криминалних радњи употребом шифрованих порука, говора тела и посебног кода. Осуђеничке банде у српском казненом систему, иако врше кривична дела са елементима насиља, не представљају такву претњу која онемогућава функционисање саме казнене установе вршењем различитих кривичних дела, те стога нема потребе за посебном заштитом комуникације чланова колектива. Уједно, у Казнено-поправном заводу у Нишу могуће је да чланови једног колектива позову члана другог колектива да им се придружи у свакодневном разговору, што је код америчких банди осуђеника скоро немогуће. Другим речима, када не постоји сукоб између два колектива, свако са сваким може да прича. Међутим, избијање сукоба између два колектива за резултат има да само вође колектива могу међусобно да причају. Смиривањем страсти комуникација се постепено обнавља код свих чланова колектива у сукобу.

У Казнено-поправном заводу за малолетнике у Ваљеву комуникација међу члановима различитих колектива не постоји било да постоји сукоб међу њима, било да таквог сукоба нема. Комуникација се одвија само преко вођа различитих колектива. Ипак, комуникација између чланова различитих колектива одвија се током ноћи у спаваони у којој заједно бораве чланови различитих колектива, при чему се води рачуна да нико од осталих чланова колектива не чује да се таква комуникација одвија. Кршење правила о забрани комуникације са чланом супротног колектива доводи до пребијања члана који је ово правило прекршио од стране чланова сопственог колектива.

\section{КОДЕКС ПОНАШАҢА}

Затвореници се свакодневно, поред утицаја формалног система, налазе и под утицајем неформалног система. Наиме, пенолози називају утицај неформалног система на затворенике затвореничка супкултура, која се одлукује употребом специфичног језика, као и неформалних норми. ${ }^{2}$ Скуп неформалних норми понашања затвореника чине тзв. кодекс понашања. Овим нормама, које су иначе кратке и јасне, одређује се понашање осуђеника не само према формалном систему већ и према другим члановима неформалног система (Константиновић Вилић, Костић, 2006, стр. 229). Овим правилима се упозоравају новопридошли затвореници да морају строго да воде рачуна о свом понашању како би избегли сукоб са затвореницима који се већ налазе на издржавању казне затвора. Један од примера

${ }^{2}$ Prisons: Prisoners - Inmate Subcultures And Informal Organizations, http://www. policemag.com/blog/gangs/story/2011/04/inmate-codes-of-conduct-and-green-lightlists.aspx, 10. јануар 2016. 
кодекса понашања, како је то пенолог Хасине (Hassine) истакао, гласи: „Немој да се коцкаш, не петљај се са дрогом, немој да имаш контакт са хомосексуалцима, не кради, не позајмљуј или не дај новац на позајмицу, и онда можда преживиш". Затвореници који се не држе ових правила понашања постају жртве манипулативних и јаких затвореника. Наиме, ти затвореници служе са уношење наркотика у казнену установу путем својих телесних шупљина или постају проститутке које сваки иоле јачи затвореник сексуално искоришћава. ${ }^{3}$

Поред Хасине, постоји и други пенолози, попут Грешама Сајкса (Gresham Sykes) и Шелдона Месинџера (Sheldon Messinger), који су се бавили кодексом понашања затвореника. Њих двојица су приликом анализе живота у казненим установама дефинисали пет правила понашања у америчким казненим установама. Прво правило односи се на понашање затвореника према другим затвореницима, као и члановима формалног система. Стога се у прво правило понашања може побројати следеће: 1) забрана мешања једног затвореника у интересе другог затвореника; 2) забрана потказивања другог осуђеника; 3) не буди бучан; 4) немој да имаш „лабаве” усне; 5) чувај леђа другом затворенику и 6) буди лојалан другом затворенику. Наредно правило односи се норме којима се контролишу емоције затвореника. Наиме, норме, попут „не губи главу”, као и „буди сталожен и посвети се свом времену", имају за циљ да спрече могуће сукобе међу затвореницима. Правила „не експлоатиши друге затворенике”, „не крши дату реч”, „не кради од других затвореника”, „не продај своје услуге”, „не буди рекеташ”, „буди праведан” користе се како би се међу затвореницима успоставила сарадња. Наредна група норми треба да послужи за одржавање достојанства међу самим затвореницима, те стога постоје правила попут „не плачи”, „не пренемажи се”, „не буди слабић”, „буди човек” итд. Последња група правила имају за циљ забрану поштовања припадника формалног система. Наиме, правилом да су „затвореници увек у праву, а да су чувари будале и да према њима увек мораш да имаш сумњу и да им не верујеш" тежи се недавању значаја контакта затвореника са члановима формалног система, чиме се процес ресоцијализације додатно отежава. Наведеним правилима наглашавају се три начела: 1) одржавање јединства, избегавање експлоатисања и конфликата, 2) одржавање себе и свог времена и 3) одржавање дистанце од чувара (Singh, 1979, p. 90).

Интервјуом са затвореницима у Казнено-поправном заводу у Нишу сазнато је каква правила понашања чине кодекс затвореника који су чланови одређених колектива. Основно правило за сваки од

\footnotetext{
${ }^{3}$ Prisons: Prisoners - Inmate Subcultures And Informal Organizations, http://www. policemag.com/blog/gangs/story/2011/04/inmate-codes-of-conduct-and-green-lightlists.aspx, 10. јануар 2016.
} 
колектива у нишком Казнено-поправном заводу је „исправност”, при чему се под тиме подразумева да ли је одређени затвореник цинкарош или не. Стога се, зарад спречавања цинкарења, сваки одлазак код васпитача организује тако да затвореник из једног колектива иде у пару са чланом супротног колектива, чиме се спречава могућност цинкарења. Наредно правило које постоји међу члановима колектива јесте забрана дрогирања. Постојање овог правила изазива доста контроверзи, ако знамо да близу 60\% затвореника, како су показало раније истраживања, користе психоактивне супстанце. Разлог постојања овог правила доста је практичан. Наиме, иако би многи сматрали да ово правило постоји како би се спречили будући сукоби због немогућности враћања новца којим су се куповали наркотици, разлог је крајње једноставан. Потреба за психоактивним супстанцама доводи до тога да лице које је узима приликом добијања пакета од стране чланова своје породице или пријатеља није у стању да пакет дели, јер му је све потребно како би купио нову количину психоактивне супстанце. Бити храбар, као наредно правило понашања међу члановима колектива, веома је битно зарад одржавања снаге одређеног колектива. Уколико дође до кршења неког од правила понашања, долази до шамарања затвореника који је одређено правило прекршио. Чак може доћи и до употребе ножа против датог лица. Најстроже санкције примењују се према цинкарошу. Наиме, до штанглирања, као што смо већ споменули, долази у случају цинкарења, при чему се примена насиља према цинкарошу наставља чак и када он буде пребачен у одељење појачаног надзора, јер колективи у сваком крилу затвора имају своје чланове који су спремни да изврше заповест вође колектива без поговора.

Број правила која регулишу понашање чланова колектива у Казнено-поправном дому за малолетнике у Ваљеву већи је у односу на број правила из нишког затвора. Ипак, прво правило из Казненопоправног завода за малолетнике у Ваљеву је идентично оном из Казнено-поправног завода у Нишу - забрана цинкарења. Уједно, правило којим се онемогућавала могућност цинкарења је забрана било каквог контакта са члановима формалног система. Наредно правило је веома битно за очувања сопственог положаја и даљег напредовања унутар одређеног колектива - буди храбар. Правило битно за хијерархију је правило о поштовању старијих момака. „Не склањај се ако ти неко иде у сусрет” је правило повезано са храброшћу. Слична је ситуација и са следећим правилом - не лутај погледом. У случају да луташ погледом, постоји могућност да се сусретнеш погледима са неким другим малолетником, што ће довести до тога да један мора да испадне кукавица када скрене поглед. Правило „не бламирај се" има везе са одржавањем статуса опаких момака. У Ваљеву је комуникација између чланова различитих колектива могућа само 
преко вођа, те стога постоји правило о забрани међусобне комуникације чланова различитих колектива. Уједно, постоји забрана свађе са члановима других колектива без претходне консултације са члановима сопственог колектива. Постоје правила везана за одржавање хигијене и здравог начина живота. Наиме, правило „буди чист” односи се на потребу одржавања личне хигијене редовним купањем. Правила „тренирај” и „забрана терапије (забрана узимања било којих лекова)" односе се на одржавање здравог начина живота. Кршење правила која се односе на забрану цинкарења, поштовање старијих момака, свађе са другим малолетницима, као и причање са члановима других колектива - за резултат има примену насиља према члану колектива који се није придржавао одређеног правила. Другим речима, долази до штанглирања, бодења, те избацивања из колектива.

\section{ЗАКЉУЧАК}

Осуђеничке банде, тзв. колективи, који постоје у казненим установама у Републици Србији захтевају примену лонгитудиналних студија ради даљег сазнавања карактеристика које их одликују. Такође, само на тај начин могуће је пратити даљи развој колектива, при чему је неопходно радити на мерама за стављање под контролу опасности не само по цео неформални и формални систем већ и на само друштво, јер бивши чланови колектива настављају да се баве криминалним радњама, између осталог, и због набављања психоактивних супстанци, које се након тога уносе у казнену установу.

Променом начина рада припадника формалног система могуће је не само ставити под контролу капацитет за бављење криминалним активностима колектива већ је могуће успети дезинтегрисати структуру колектива. Наиме, као пример за последњу тврдњу можемо навести тренутно стање у Казнено-поправном заводу у Нишу. Постављењем видео-надзора где год је то могуће припадници колектива не могу више неометано да се баве криминалним радњама, јер ће врло брзо бити откривени. Пре последње реконструкције затворског комплекса постојао је један тоалет по затворском крилу, што је резултирало тиме да се спаваоне током ноћи не закључавају. Овако стање одговарало је колективима, јер се на тај начин успешно продавала и конзумирала дрога, организовало коцкање и друге недозвољене активности. Улагањем додатннх финансијских средстава у побољшање услова боравка затвореника у нишком Казнено-поправном заводу дошло је до изградње по тоалета у свакој од спаваона, чиме су услови за бављење недозвољеним активностима нестали. Потреба за кријумчарењем мобилних телефона и њиховом продајом од стране чланова колектива више не постоји, јер сада телефонске говорнице постоје унутар сваког крила, те је могућност разговора са члановима 
породице, као и пријатељима, неограничена, а уједно постоје и локатори за мобилне телефоне. Као успешно средство у борби против конзумирања наркотика показало се увођење редовних и ванредних тестова на употребу дрога. Уколико неко од затвореника буде позитиван на тесту, могућност његовог напредовања у смештају је знатно мања. На тај начин на наркоманима је додатни притисак да мање конзумирају наркотике, чиме се одузима једна од најпрофитабилнијих криминалних активности различитих колектива. Последњи разлог смањивања снаге колективима у Казнено-поправном заводу у Нишу је и строга примене нормативних решења о напредовању затвореника ка полуотвореном одељењу. Пре доласка нове управе у нишки затвор, давање повластица затвореницима се ретко примењивало, иако су били испуњени законски услови. Стога код већине затвореника постоји жеља да побољшају свој положај унутар казнене установе, а не да га отежавају криминалним активностима које се спроводе од стране колектива. На промену функционисања формалног система зарад борбе, између осталог, и против колектива, неки од чланова колектива имају изразито негативни став, који се најбоље одсликава у реченици „Не дају нам ни да робијамо лепо”, јер само условно речено „мир” у казненој установи без свакодневног надзора и контроле омогућава бављење криминалним активностима чланова колектива. Међутим, постоји и ставови супротни од овог, који се отелотворују у томе да појединим члановима колектива овакве промене пријају, јер не морају да живе у константном опрезу од насиља.

Пракса у казнено-поправном заводу треба да послужи као пример успешном супротстављању колективима. Стога је неопходно да друге казнене установе, попут Казнено-поправног завода за малолетнике у Ваљеву, примене комбинацију мера из нишког Казненопоправног завода, с циљем смањивања криминалних активности колектива. Уједно, успешно супротстављање колективима захтева даље спровођење пенолошких студија лонгитудиналног карактера.

\section{ЛИТЕРАТУРА}

C. H. Orthmann, K. Hess, K., Criminal Investigation, Cengage Learning, New York, 2012, 598.

C. Hensley, Prison Sex: Practice and Policy, Lynne Rienners Publishers, Colorado, $2002,4$.

D. Orlando-Morningstar, Special needs offenders - Bulletin, 1997, 5 https://bulk. resource.org/courts.gov/fjc/snobull2.pdf, 27. јун 2013

G. L. Mays, L. T. Winfree, Essentials of Corrections, Cengage Learning, New York, 2008, 208.

I. Singh, Indian Prison: A Sociological Enquiry, Concept Publishing Company, New Delhy, 1979, 90.

L. Miller, K. Hess, C Orthmann, C., Community Policing: Partnerships for Problem Solving, Cengage Learning, New York, 2011, 386. 
M. Fleisher, S. Decker, An Overview of the Challenge of Prison Gangs, Aspen Publishers, 5(1), 2001, 2.

M. Lyman, Drugs in Society: Causes, Concepts and Control, Anderson Publishing, Burlington, 2011, 497.

P. Carlson, J. Simon Garrett, Prison and Jail Administration: Practice and Theory, Jones and Bartlett Publishers, Canada, 2008, 32.

Prison Gang Law \& Legal Definition, http://definitions.uslegal.com/p/prison-gang/, 23. јун 2013.

Prisons: Prisoners - Inmate Subcultures And Informal Organizations, http://www.policemag. com/blog/gangs/story/2011/04/inmate-codes-of-conduct-and-green-light-lists.aspx, 10. јануар 2016.

R. Holmes, R. Tewksbury, G. Higgins, 121.

R. Holmes, R. Tewksbury, G. Higgins, Introduction to Gangs in America, Taylor \& Francis Group, USA, 2012, 120.

R. Riviello, Manual of Forensic Emergency Medicine, Jones and Bartlett Publishers, London, 2010, 196.

T. Clear, G., Cole, M, Reisig, American Corrections, Thomson Higher Education, USA, 2009, 278.

М. Костић, Д. Димовски, „Осуђеничке банде у Сједињеним Америчким Државама" [Prisoner's gangs in the United States], Зборник радова Правног факултета у Нишу, Правни факултет у Нишу, Ниш, 2013, 221.

С. Константиновић Вилић, М. Костић, Пенологија - општи део [Penology general part], Свен, Ниш, 2006, 229.

\section{CHARACTERISTICS OF PRISON GANGS IN THE REPUBLIC OF SERBIA}

Darko Dimovski, Miomira Kostić

University of Niš, Faculty of Law, Niš, Serbia

\section{Summary}

Starting from the concept prison gangs, who have given famous penologists Carlson, Garrett, Fleischer, Reason and others, the author pointed out that until now the subject of empirical research were not gangs of inmates in penitentiary institutions of the Republic of Serbia. Therefore, it was necessary to conduct a study to determine the characteristics of prison gangs in Serbia, where it came to comparing the results obtained with the characteristics of a gang of convicts in the US penitentiary system. The author has analyzed the structure of prison gangs in a correctional institution in Niš and in a correctional institution for juveniles in Valjevo, stating the mode of progression in the structure of gangs. The basis of the existence of gangs in prisons is engaging in criminal activities. Before he dealt what are the criminal activities of prison gangs in a correctional institution in Niš and in a correctional institution for juveniles in Valjevo, the author stated that the crimes carried out gangs of prisoners in US jails, noting that these criminal activities do not differ. One of the ways of carrying out criminal activities in prisons is the use of violence. While data on violence among convicts gangs in American prisons can be easily reached, the management of the correctional facility in Niš, as well as in a correctional institution for juveniles in Valjevo, does not keep such records, and it is impossible to know whether a particular violence in penitentiry institution has been set up as a result of relations in a 
prisoner gangs, and as a result of the conflict with the other prisoners' band, or due to other circumstances. However, in addition to the use of violence by prisoners' gang is due to code violations. Communication of prison gangs must be done in a discreet way with hindering information messages transmitted by the prison administration. Therefore, using a variety of encrypted messages in American prisons. Unlike them, the gang of convicts in a correctional facility in Niš and in a correctional institution for juveniles in Valjevo do not use an encrypted message, body language to communicate with each other, as well as a special code. The reason for this is the fact that prisoners' gang in prison in Niš and in prison for juveniles in Valjevo do not pose such a threat that prevents the functioning of the penitentiary institution committing various criminal acts, and therefore there is no need for special protection of communications of members of the prison gangs. The last part is dedicated to the code of conduct, stating the rules that must be respected. 